\title{
PENGEMBANGAN BAHANAJAR BAHASA INDONESIA BERBASIS BUDAYA LOKAL BALIDI KELAS VII SMP PGRI 3 DENPASAR
}

\author{
I Nyoman Adi Susrawan ${ }^{1}$, Dewa Gede Bambang Erawan ${ }^{2}$ \\ Fakultas Keguruan dan Ilmu Pendidikan Unmas Denpasar ${ }^{1}$ \\ Email:adisusrawan1988@gmail.com
}

\begin{abstract}
ABSTRAK
Penelitian ini merupakan penelitian pengembangan yang bertujuan (1) mendeskripsikan dan mengidentifikasi proses rancang bangun dan kelayakan bahan ajar bahasa Indonesia berbasis budaya Bali,(2) untuk mendeskripsikan dan menganalisis respon siswa kelas VII SMP PGRI 3 Denpasar terhadap pengembangan bahan ajar bahasa Indonesia berbasis budaya lokal Bali. Data dalam penelitian pengembangan ini diperoleh melalui metode observasi, wawancara, dan angket. Data yang telah terkumpul selanjutnya dianalisis dengan analisis deskriptif kualitatif dan analisis deskriptif kuantitatif.Hasil penelitian menunjukkan bahwa pengembangan bahan ajar bahasa Indonesia berbasis budaya lokal Bali termasuk ke dalam kategori sangat baik. Hal itu bertolak dari hasil validasi oleh ahli isi mata pelajaran yang memberikan penilaian dengan skor rata-rata 88,42 . Hasil pelaksanaan uji coba, baik uji coba lapangan awal dan uji coba lapangan utama juga menunjukkan skor rata-rata 90,28 dan 92,50 termasuk dalam kategori sangat baik. Tidak hanya itu, respon yang baik juga diperoleh dalam penelitian ini, secara keseluruhan skor rata-rata yang diberikan oleh siswa sebagai pengguna bahan ajar adalah 4,45 termasuk dalam kategori sangat positif. Dengan demikian dapat disimpulkan bahwa bahan ajar yang dikembangkan sudah layak digunakan dalam proses pembelajaran.
\end{abstract}

\section{Kata Kunci : bahan ajar, budaya lokal}

\begin{abstract}
This research categorized as Research and Devenlopment ( $R \& D)$ that aims to (1) describe and identify the design process and the feasibility of learning materials of Bali based on Balinese culture, (2) to describe and analyze the responses of VII grade students of SMP PGRI 3 Denpasar towards the development of Indonesian language based materials of local culture Bali. The data obtained through observation, interview, and questionnaire methods. Furthermore, the collected then analyzed by qualitative descriptive analysis and quantitative descriptive analysis. The results showed that the development of Indonesian language learning materials based on local Balinese culture included into very well category. It was based on the validation results by the subject matter expert who gave an assessment with an average score of 88.42. The results of the pilot test, both initial field trials and major field trials also showed an average score of 90.28 and 92.50 included in the excellent category. Moreover, a good response is also obtained in this study, the overall average score given by students as users of teaching materials is 4.45 included very positive category. Thus, it can be concluded that the developed teaching materials are feasible to be used in the learning process.
\end{abstract}

Keywords: teaching materials, local culture PENDAHULUAN

Keberhasilan sebuah proses belajarmengajar tidaklah semata-mata ditentukan oleh pengajar yang handal, input yang baik, dan fasilitas pengajaran seperti gedung sekolah, alat-alat pengajaran, perpustakaan,

dan sebagainya yang memadai, tetapi pemilihan bahan ajar yang tepat dan berkualitas juga memegang peranan yang cukup dominan (Wijaya dan Rohmadi, 2009:239). Penyunan bahan ajar yang berkualitas akan memberikan dampak yang 
positif kepada para siswa, diantaranya siswa akan tertarik dan tumbuh minatnya untuk memenuhi dan menguasai materi yang telah diberikan, serta proses pembelajaran menjadi lebih bermakna. Selain itu, bahan ajar yang dikembangkan juga harus mampu menjadi sarana pembimbing budi pekerti peserta didik. Hal itu dapat dilakukan dengan cara menyelipkan atau memilih bahan ajar yang memuat nilai-nilai moral yang baik. Pernyataan tersebut senada dengan apa yang dikemukankan oleh Iskandarwassid dan Sunendar (2009:172), yang menyatakan bahwa salah satu kriteria pemilihan bahan ajar adalah bahan ajar harus mampu menstimulus aktivitasaktivitas pribadi para peserta didik, yang nantinya dapat menjadi pedoman hidup. Jadi, hal tersebut mengisyaratkan bahwa sebuah bahan ajar harus mampu memberikan bimbingan kepada peserta didik, yang dikemudian hari dapat dijadikan stimulus untuk menunjukkan aktivitasaktivitas atau perilaku yang lebih baik.

Namun, sangat disayangkan pernyataan tersebut tidak sesuai dengan kenyataan di lapangan. Dalam proses pembelajaran belum semua guru mampu mengembangkan bahkan menyusun bahan ajar secara mandiri. Para guru selama ini masih mengandalkan buku paket dan LKS. Lebih lanjut, hasil diskusi peneliti dengan kepala sekolah dan beberapa guru bahasa Indonesia di SMP PGRI 3 Denpasar terungkap bahwa para guru megalami kesulitan dalam membuat bahan ajar terutama pemilihan materi yang relevan dengan karakteristik peserta didik. Dalam pelaksanaan pembelajaran para guru lebih cenderung berpatokan pada buku LKS tanpa dibarengi atau diimbangi dengan pemilihan materi yang dekat dengan karakteristik siswa. Hal ini tentunya berimbas pada aktivitas dan hasil belajar siswa yang tidak sesuai dengan harapan. Untuk mengatasi hal tersebut peneliti mencoba untuk menawarkan alternatif solusi dengan jalan melakukan sebuah penelitian berkaitan dengan pengembangan bahan ajar berbasis budaya lokal Bali yang relevan dengan konsep-konsep bahasa Indonesia.

Pembelajaran berbasis budaya lokal Bali merupakan strategi penciptaan lingkungan belajar dan perancangan pengalaman belajar yang mengintegrasikan budaya lokal. Dalam pembelajaran berbasis budaya lokal Bali, budaya lokal menjadi sebuah media bagi siswa untuk mentransformasikan hasil observasi mereka ke dalam bentuk prinsip-prinsip yang kreatif. Dengan demikian, melalui pembelajaran berbasis budaya lokal Bali, siswa bukan sekedar meniru dan/atau menerima saja informasi yang disampaikan, tetapi siswa menciptakan makna dan pemahaman dari informasi yang diperolehnya. Demikian juga, pembelajaran berbasis budaya lokal Bali bukan sekedar menstransfer atau menyampaikan perwujudan budaya lokal, tetapi menggunakan budaya lokal untuk menjadikan siswa mampu menciptakan makna, menembus batas imajinasi, dan kreativitas untuk mencapai pemahaman yang mendalam tentang materi subyek yang dipelajarinya, Sardjiyo dan Pannen (2005).

Hal senada juga disampaikan Ausubel (dalam Suastra, 2009) yang mengatakan bahwa hal yang paling penting dalam belajar adalah apa yang telah diketahui siswa. Dalam pembelajaran berbasis budaya, lingkungan belajar akan berubah menjadi lingkungan yang menyenangkan bagi guru dan siswa, yang memungkinkan guru dan siswa berpartisipasi aktif berdasarkan budaya yang sudah mereka kenal, sehingga dapat diperoleh hasil belajar yang optimal. Siswa merasa senang dan diakui keberadaan serta perbedaannya, karena pengetahuan dan pengalaman budaya yang sangat kaya yang mereka miliki dapat diakui dalam proses pembelajaran. Sementara itu, I 
Wayan Suastra, dkk. (2011:267) dalam temuan penelitiannya menyatakan bahwa pembelajaran berbasis budaya mampu menggeser pembelajaran dari pembelajaran yang menggunakan hafalan menjadi pembelajaran yang menghubungkan suatu konsep dengan fakta yang ada dalam kehidupan sehari-hari. Selain itu, model pembelajaran berbasis budaya didisain berdasarkan prinsip-prinsip pembelajaran konstruktivisme di mana pengetahuan dibangun sendiri oleh siswa (student centered), sedangkan guru hanya sebagai fasilitator dan mediator. Guru tidak perlu mentransfer semua pengetahuan kepada pebelajar tetapi mengajak pebelajar untuk berpikir dan mencari jawaban sendiri atas permasalahan yang diberikan oleh guru maupun pebelajar itu sendiri melalui diskusi kelas maupun diskusi kelompok berdasarkan pengalaman mereka yang telah diperoleh dari kehidupan sehari-hari.

Walaupun pembelajaran berbasis budaya Bali sudah terbukti efektif meningkatkan hasil belajar siswa, namum guru-guru belum banyak yang memahaminya. Hal ini sejalan dengan temuan penelitian dari Suja et al. (2007) bahwa guru-guru SMP belum memahami budaya lokal yang dapat diintegrasikan ke dalam pembelajaran, walaupun sesungguhnya tanpa disadari mereka telah menyinggungnya dalam pembelajaran. Berdasarkan latar belakang tersebut maka penelitian yang berjudul Pengembangan Bahan Ajar Bahasa Indonesia Berbasis Budaya Lokal Bali di Kelas VII SMP PGRI 3 Denpasarpatut dilaksanakan. Dalam penelitian ini peneliti membatasi masalah berdasarkan uraian masalah, tujuan dan analisis kebutuhan di atas. Adapun batasan masalah dalam penelitian ini adalah (1) Pengembangan bahan ajar pembelajaran berbasis kearifan lokal Bali sebagai materi pelajaran bahasa Indonesia yang dikembangkan sesuai dengan karakteristik siswa, (2) bahan ajar yang dikembangkanterfokus pada satu Standar Kompetensi (SK) dan satu Kompetensi Dasar (KD) pada masing-masing aspek keterampilan berbahasa. Hal ini didasarkan pada kenyataan bahwa bahasa merupakan sarana komunikasi yang efektif sehingga bahan pelajaran untuk membangun kemampuan berbahasa, baik menyimak, berbicara, membaca, dan menulis perlu didesain berbasis komunikasi nyata.

\section{METODE PENELITIAN}

\section{Desain Penelitian}

Pengembangan bahan ajar ini menggunakan rancangan penelitian pengembangan (Research andDevelovment). Prosedur penelitian ini terdiri atas beberapa tahapan, diantaranya sebagai berikut.

\section{1) Penelitian Pendahuluan}

Penelitian pendahuluan dilakukan untuk mengumpulkan dan mengidentifikasi informasi terkait permasalahan yang dijumpai dalam pembelajaran.

\section{2) Tahap Perencanaan}

Pada tahap perencanaan, hal-hal yang dilakukan oleh peneliti meliputi penyusunan bahan ajar. Dalam tahap penyusunan bahan ajar, silabus, RPP, dan bahan ajar yang dimiliki guru mata pelajaran bahasa Indonesia dikumpulkan untuk menentukan materi bahan ajar yang akan disusun. Selain itu, pada tahap ini juga dilakukan pengumpulan bahan ajar bahasa Indonesia berbasis budaya Bali.

3) Tahap Pengembangan Bahan Ajar

Kegiatan yang dilakukan pada tahap ini adalah menyusun bahan ajar bahasa Indonesia berbasis budaya lokal Bali. Hal-hal yang dicantumkan dalam bahan ajar, 
yakni identitas mata pelajaran, Standar Kompetensi (SK), Kompetensi Dasar (KD), alokasi waktu, tujuan pembelajaran, materi pembelajaran, metode pembelajaran, langkah-langkah kegiatan pembelajaran, sumber belajar, dan evaluasi.

4) Validasi

Untuk mengetahui kelayakan dari produk yang dikembangkan berupa bahan ajar maka harus diuji tingkat validitasnya. Tingkat validitas bahan ajar diketahui melalui hasil review ahli isi mata pelajaran, validasi kelompok kecil dan validasi lapangan.

\section{5) Tahap Revisi}

Data yang diperoleh berdasarkan validasi kelompok kecil dan validasi lapangan selanjutnya dianalisis dan digunakan untuk memperbaiki atau merevisi bahan ajar yang sudah dikembangkan. Pada hasil akhirnya diharapkan produk yang dikembangkan sudah merupakan desain model operasional yang siap pakai.

\section{Waktu dan Tempat}

Penelitian ini dilaksanakan selama delapan bulan, mulai Maret 2017 sampai Oktober 2017. Penelitian ini dilaksanakan di SMP PGRI 3 Denpasar.

\section{Metode Pengumpulan Data}

Metode Pengumpulan Data merupakan teknik atau cara yang dilakukan untuk mengumpulkan data. Teknik pengumpulan data merupakan faktor penting demi keberhasilan penelitian. Hal ini berkaitan dengan bagaimana cara mengumpulkan data, siapa sumbernya, dan apa alat yang digunakan. Berdasarkan pernyataan tersebut adapun teknik pengumpulan data yang digunakan dalm penelitian ini adalah observasi, wawancara dan angket. Angket yang disusun berisi item-item pertanyaan serta saran/komentar yang akan diiisi oleh para ahli dan siswa pada saat validasi. Angket digunakan untuk mengumpulkan data hasil review dari ahli mata pelajaran, dan respon siswa.

\section{Metode Analisis Data}

Metode analisis data yang digunakan dalam penelitian pengembangan ini adalah analisis deskriptif kualitatif dan analisis deskriptif kuantitatif. "Analisis deskriptif kualitatif ini digunakan untuk mengolah data hasil review ahli isi mata pelajaran, validasi kelompok kecil dan validasi lapangan. Data hasil hasil analisis deskriptif kualitatif dari para ahli dan siswa yang beruapa saran dan kritik digunakan untuk merevisi produk yang dikembangkan. Selanjutnya metode analisis deskriptif kuantitatif digunakan untuk mengolah data dalam bentuk angka-angka dan atau persentase, mengenai suatu objek yang diteliti. Data yang diperoleh dari teknik analisis ini, berupa angka dari hasil review ahli isi mata pelajaran dan validasi siswa baik kelompok kecil maupun validasi lapangan. Rumus yang digunakan untuk menghitung persentase dari masing-masing subyek menurut Tegeh dan Kirna (2010:101) sebagai berikut.

$$
\begin{aligned}
& \text { Persentase = } \\
& \frac{\sum(\text { jawaban } \times \text { bobot tiap pilihan })}{n \times \text { bobot tertinggi }} \times 100 \%
\end{aligned}
$$

Keterangan: $\Sigma=$ jumlah

$\mathrm{n}=$ jumlah seluruh item angket

Selanjutnya, untuk menghitung persentase keseluruhan subyek digunakan rumus:

Persentase $=(\mathrm{F}: \mathrm{N})$ 
Keterangan: $\mathrm{F}=$ jumlah persentase keseluruhan subyek

$$
\mathrm{N}=\text { banyak subjek }
$$

Untuk dapat memberikan makna dan pengambilan keputusan digunakan ketetapan terhadap hasil review paraahli dan uji coba produk sebagai berikut.

Tabel 1. Konversi PAP Tingkat Pencapaian dengan skala 5

\begin{tabular}{cc}
\hline Tingkat Pencapaian (\%) & Kualifikasi \\
\hline $90-100$ & Sangat baik \\
\hline $75-89$ & Baik \\
\hline $65-74$ & Cukup \\
\hline $55-64$ & Kurang \\
\hline $0-54$ & Sangat kurang \\
\hline
\end{tabular}

(Adaptasi dari Tegeh dan Kirna, 2010:101)

\section{Hasil Penelitian}

\section{Proses Rancang Bangun dan Kelayakan Bahan Ajar Bahasa Indonesia Berbasis Budaya Bali}

Sesuai dengan prosedur penelitian yang telah dirancang, pengembangan Bahan Ajar Bahasa Indonesia berbasis budaya lokal Bali dilakukan dengan beberapa tahapan, diantaranya:

Tahap Pertama : Mengumpulkan Kurikulum, Silabus, RPP dan Bahan Ajar

Pada tahap ini peneliti mengumpulkan kurikulum, silabus, RPP dan bahan ajar yang digunakan oleh guru dalam melaksanakan proses pembelajaran. Pengumpulan kurikulum, silabus, RPP dan bahan ajar ini digunakan sebagai acuan/pedoman dalam mengembangkan bahan ajar bahasa Indonesia berbasis budaya lokal Bali. Untuk mendapatkan bahan ajar yang berkualitas, diperlukan analisis terhadap Standar Kompetensi (SK) dan Kompetensi Dasar (KD). Analisis SK KD dilakukan untuk menentukan kompetensi-kompetensi mana yang memerlukan bahan ajar.
Tahap Kedua: Mengumpulkan Bahan Ajar Berbasis Budaya Bali

Kegiatan ini merupakan tahap kedua setelah melakukan pengkajian terhadap kurikulum, silabus, RPP dan bahan ajar yang digunakan oleh guru dalam melaksanakan proses pembelajaran. Pada tahap ini, peneliti mengumpulkan dan mengidentifikasi budaya lokal Bali yang dapat diimplementasikan sebagai bahan ajar sesuai dengan SK - KD yang ingin dicapai dalam proses pembelajaran.

Tahap Ketiga : Pengembangan Bahan Ajar Pada tahap ini, peneliti mengembangkan bahan ajar bahasa Indonesia berbasis budaya Bali berdasarkan hasil analisis terhadap SK - KD. Bahan ajar yang dikembangkandalam penelitian ini terfokus pada satu SK dan KD. Adapun materi yang dikembangkan berdasarkan analisis SK KD adalah pada materi "Menulis Teks Deskripsi". Untuk lebih jelasnya berikut ini digambarkan KD, Indikator, Materi Pelajaran dan Kegiatan Pembelajaran yang diimplementasikan dalam proses pembelajaran. 
Tabel 2. Kompetensi Dasar, Indikator, Materi Pembelajaran, dan Kegiatan Pembelajaran

\begin{tabular}{|c|c|c|c|}
\hline $\begin{array}{l}\text { Kompetensi } \\
\text { Dasar }\end{array}$ & Indikator & $\begin{array}{c}\text { Materi } \\
\text { Pembelajaran }\end{array}$ & $\begin{array}{c}\text { Kegiatan } \\
\text { Pembelajaran }\end{array}$ \\
\hline $\begin{array}{l}\text { 3.1 Menulis teks } \\
\text { deskripsi tentang } \\
\text { objek (sekolah, } \\
\text { tempat wisata, } \\
\text { tempat bersejarah, } \\
\text { dan atau suasana } \\
\text { pentas seni daerah) } \\
\text { yang didengar dan } \\
\text { dibaca. }\end{array}$ & 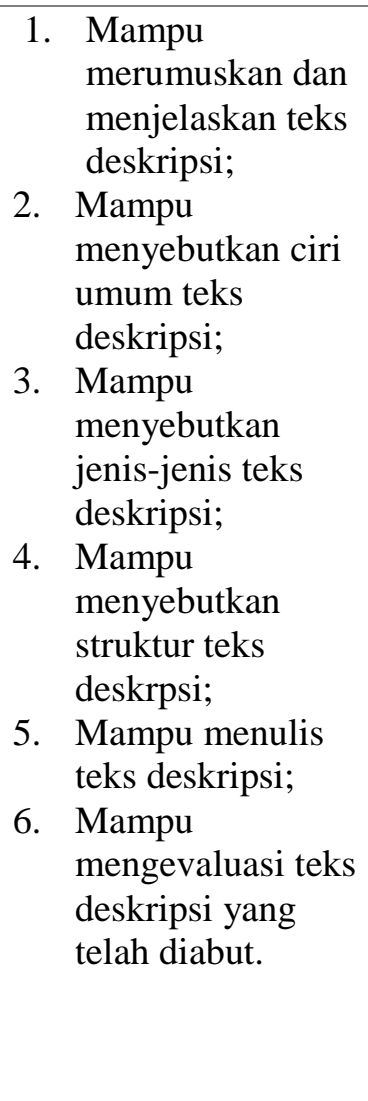 & 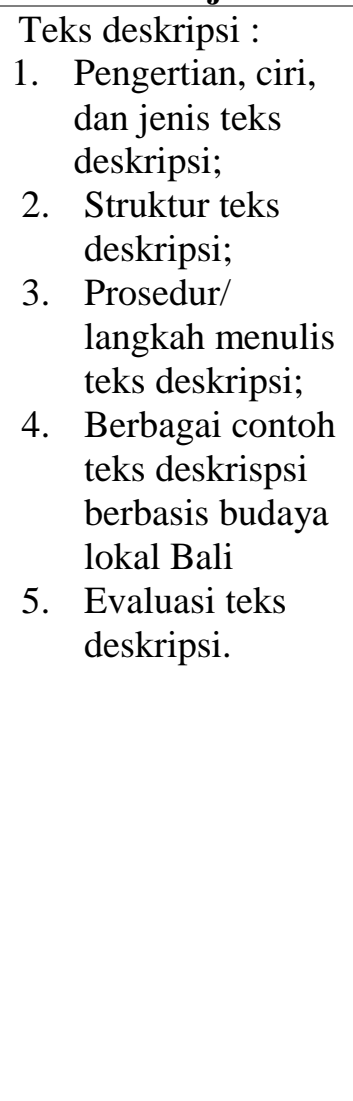 & 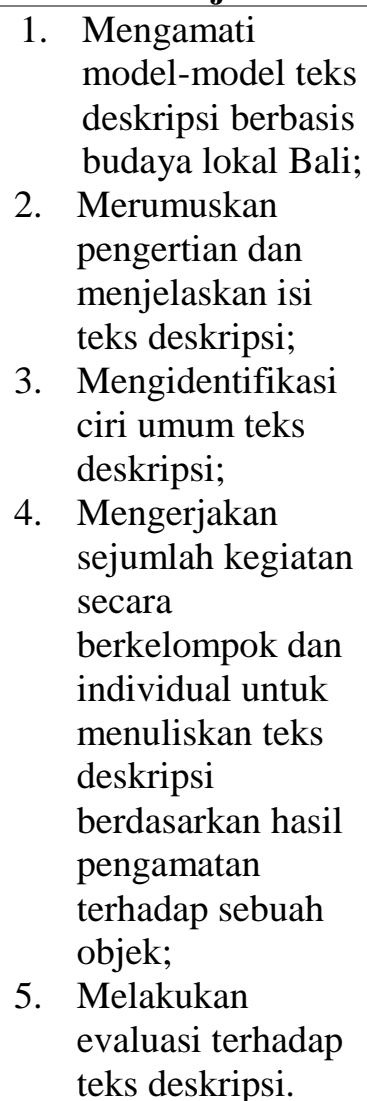 \\
\hline
\end{tabular}

Jenis bahan ajar yang dikembangkan dalam penelitian ini adalah bahan ajar berupa Handout Bahasa Indonesia berbasis budaya lokal Bali. Handout berasal dari bahasa Inggris yang berarti informasi, berita atau surat lembaran. Istilah Handout memang belum ada padanannya dalam bahasa Indonesia. Handout biasanya merupakan bahan ajar tertulis yang diharapkan dapat mendukung bahan ajar lainnya atau penjelasan dari guru. Handout adalah bahan tertulis yang disiapkan oleh seorang guru untuk memperkaya pengetahuan siswa.

Handout disusun atas dasar kompetensi dasar yang harus dicapai oleh siswa. Dengan demikian maka penyusunan handout harus diturunkan dari kurikulum. Handout biasanya merupakan bahan tertulis tambahan yang dapat memperkaya pengetahuan siswa dalam belajar untuk mencapai kompetensinya. Adapun unsurunsur yang harus ada dalam penyusunan sebuah handout adalah sebagai berikut.

a) Standar kompetensi. Adalah tujuan yang dicapai siswa setelah diberi satu pokok bahasan yang berfungsi untuk memberikan pandangan umum tentang hal-hal yang dikuasai siswa.

b) Kompetensi dasar. Adalah tujuan yang akan dicapai setelah mengikuti pelajaran untuk 1 kali pertemuan. Fungsinya untuk memberikan fokus pada siswa pada sub pokok bahasan yang sedang dihadapi.

c) Ringkasan materi pelajaran merupakan kesimpulan-kesimpulan dari bahan ajar yang akan disampaikan atau diberikan pada siswa dan telah disusun secara sistematis. Fungsinya agar 
memungkinkan siswa dapat mengetahui sistematika pelajaran yang harus dikuasai, sekaligus memandu siswa dalam pengayaan diluar proses mengajar dikelas.

d) Latihan. Adalah permasalahan yang harus diselesaikan siswa setelah ia menerima atau mempelajari materi pelajaran tersebut, penyelesaian soal itu dikumpul atau dinilai, kemudian dibahas secara bersama-sama untuk membantu siswa dalam melatih memahami materi pelajaran yang akan diberikan.

e) Sumber bacaan. Adalah buku atau bahan ajar apa saja yang akan digunakan atau menjadi sumber dari materi pelajaran yang diberikan. Fungsinya untuk menelusuri lebih lanjut materi pelajaran yang akan disampaikan.

Berikut ini adalah langkah-langkah yang dilakukan oleh peneliti untuk mendapatkan handout yang sesuai dengan kompetensi dasar yang ingin dicapai.

Gambar 1. Langkah-langkah pembuatan Handout

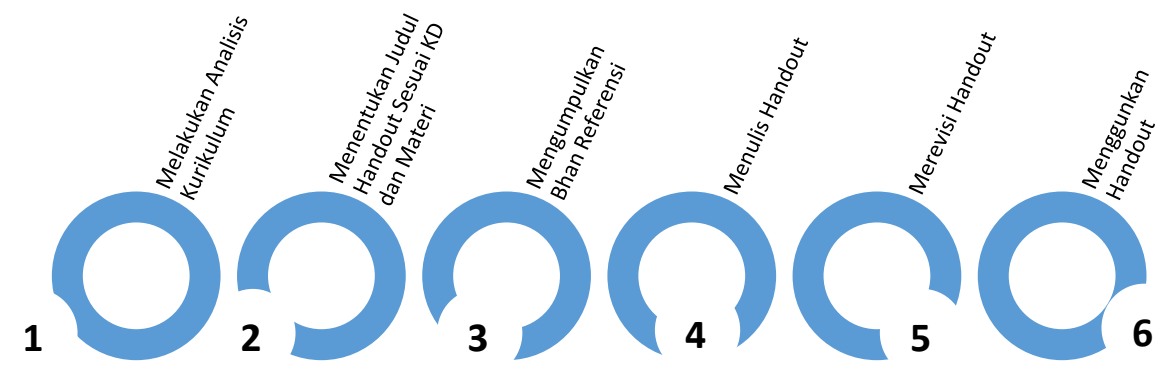

Tahap Keempat : Validasi Bahan Ajar

Untuk mendapatkan kualitas bahan ajar yang baik, bahan ajar yang dikembangkan tersebut harus divalidasi oleh para ahli. Validasi bahan ajardilakukan dengan tujuan untuk meminimalisir kesalahan-kesalahan yang terdapat dalam bahan ajar sebelum diimplementasikan dalam proses pembelajaran. Teknik yang digunakan untuk menilai bahan ajar adalah dengan kuesioner. Kuesioner diberikan ahli isi mata pelajaran. Adapun kompenen evaluasi mencakup kelayakan isi, kebahasaan, sajian, dan kegrafisan. Data hasil evaluasi selanjutnya dianalisis secara deskriptif kualitatif dan deskriptif kuantitatif. Hasil analisi deskriptif digunakan untuk menganalisi data berupa berupa masukan, saran dan komentar digunakan sebagai acuan untuk melakukan revisi terkait bahan ajar, sedangkan analisi deskriptif kuantitatif digunakan untuk mempresentasekan hasil kuesioner selanjutnya dikonversi ke dalam tingkat pencapaian dengan skala 5. Berdasarkan hasil evaluasi tersebut, selanjutnya peneliti dapat melakukan revisi atau perbaikan terhadap bahan ajar yang dikembangkan. Setelah itu, bahan ajar siap untuk dimanfaatkan dalam proses pembelajaran. Berikut ini dijabarkan hasil penelitian berdasarkan validasi ahli mata pelajaran dan uji coba lapangan.

\section{1) Validasi Ahli Isi Mata Pelajaran}

Untuk mendapatkan validasi ahli isi mata pelajaran digunakan angket tertutup yang terdiri atas 19 pertanyaan. Hasil angket tertutup tersebut menunjukkan skor rata-rata 88,42. Hal ini mengindikasikan bahwa bahan ajar yang dikembangkan 
termasuk pada kualifikasi baik. Tidak hanya itu, komentar berupa saran juga disampaikan ahli isi melalui angket terbuka terkait bahan ajar yang dikembangkan. Ada banyak saran yang diberikan oleh ahli isi, diantaranya (1) indikator capaian pembelajaran yang perlu diperjelas. Pada awalnya bahan ajar yang dikembangkan tidak berisi indikator capaian pembelajaran, padahal indikator capaian pembelajaran penting dalam proses belajar, yakni untuk mengukur tingkat keberhasilan materi yang diberikan. (2) mengenai kejelasan gambar pada materi ajar. Gambar yang ditampilkan sudah sesuai dengan isi teks. Namun, gambar yang ditampilkan hendaknya gambar yang terbaru. Hal ini sejalan dengan pendapat Ismawati (2012) yang mengemukakan bahwa materi ajar yang ideal adalah materi ajar yang benar-benar nyata, sebagaimana yang ada dalam kehidupan yang menyesuaikan dengan perkembangan zaman serta didikung oleh tampilan fisik yang menarik. Selain itu, tim ahli memberikan masukan terkait mengenai ejaan. Penulisan ejaan dalam materi ajar hendaknya sesuai dengan kaidah penggunaan bahasa Indonesia yang baik dan benar karena materi ajar ini digunakan dalam pembelajaran bahasa Indonesia. Materi ajar yang disusun bisa dijadikan acuan oleh peserta didik dalam menggunakan bahasa Indonesia yang baik dan benar.

Selain memberikan masukan terkait pengembangan bahan ajar, ahli isi juga memberikan catatan mengenai kelebihan bahan ajar yang dikembangkan. Ahli isi menyatakan bahwa bahan ajar yang dikembangkan sudah sesuai dengan kurikulum 2013. Bahan ajar yang dikembangkan lebih mudah untuk dipelajari karena bahan ajar yang disusun sangat kontekstual serta mengangkat budaya lokal Bali.
Catatan menarik lainnya yang diberikan oleh ahli isi adalah mengenai kelebihan bahan ajar ini dari segi variasi komposisi bahan ajar. Variasi ini menyangkut ragam komponen bahan ajar yang disajikan dan tampilan gambar yang kontekstual. Penggunaan gambar yang kontekstual mampu menarik perhatian para siswa. Tampilan bahan ajar yang dekat dengan kehidupan nyata berimplikasi pada keingitahuan siswa untuk memahami isi dari bahan ajar.

Secara umum, semua masukan yang diberikan oleh ahli isi mata pelajaran dievaluasi dan dijadikan sebagai referensi untuk memperbaiki bahan ajat yang dikembangkan.

\section{2) Uji Coba Lapangan}

Pelaksanaan uji coba lapangan dilakukan melalui dua tahap, diantaranya uji coba lapangan awal dan uji coba lapangan utama. Berdasarkan hasil uji coba lapangan awal yang diikuti oleh tujuh orang melalui angket tertutup yang terdiri atas 10 pernyataan menunjukkan kualifikasi sangat baik dengan rata-rata 90,28. Selain terdapat pertanyaan tertutup pada angket yang diberikan, juga terdapat satu pertanyaan terbuka, yakni mengenai komentar secara garis besar mengenai materi ajar yang digunakan. Secara garis besar komentar siswa pada tahap awal ini yakni mengenai penulisan. Penulisan huruf dalam materi ajar tersebut masih ada yang salah, misalnya kekurangan huruf ataupun kelebihan. Siswa merasa kesulitan ketika mememui hal tersebut. Akan tetapi, sejauh kembali ditegaskan oleh guru, siswa dapat memahaminya.

Sama hanya dengan uji lapangan awal, tahap uji lapangan utama juga dilakukan dengan menyebarkan kuesioner kepada siswa, hanya saja jumlah siswa yang ikut dalam uji lapangan utama ini lebih banyak dibandingkan dengan uji lapangan 
awal. Berdasarkan uji lapangan utama, skor rata-rata yang diperoleh melalui angket tertutup yang terdiri atas 10 pernyataan terhadap 21 orang menunjukkan kualifikasi sangat baik dengan rata-rata 92,50. Selain terdapat pertanyaan tertutup pada angket yang diberikan, juga terdapat satu pertanyaan terbuka, yakni mengenai komentar secara garis besar mengenai materi ajar yang digunakan. Secara garis besar komentar siswa pada tahap lapangan utama ini yakni sudah sangat baik. Namun, beberapa siswa masih menemukan adanya kesalahan pengetikan. Akan tetapi, intensitas kesalahannya sangat sedikit.

Jika diamati dari aktivitas dan hasil belajar siswa dengan mengimplmentasikan bahan ajar bahasa bahasa Indonesia berbasis budaya lokal Bali menunjukkan hasil yang baik, yaitu $82 \%$ siswa mendapatkan skor di atas Kreteria Ketuntasan Minimal (KKM) yang ditetapkan di SMP PGRI 3 Denpasar. Peningkatan aktivitas dan hasil belajar ini disebabkan karena beberapa alasan, diantaranya:

Pertama, dilihat dari segi landasan teoretis, bahan ajar berbasis budaya dapat melatih kepekaan siswa untuk mendeskripsikan dan mengidentifikasi budaya lokal yang ada disekitar siswa. Mengawali pembelajaran siswa diminta untuk mengungkapkan gagasan, ide, pengetahuan dan bahkan keyakinannya terhadap objek atau fenomena alam maupun sosial budaya di sekitar siswa yang terkait dengan pelajaran yang akan dipelajari. Hal ini sesuai dengan pendapatnya Ausubel (dalam Suastra, 2009) yang mentakan bahwa hal yang paling penting dalam belajar adalah apa yang telah diketahui siswa.

Kedua, pembelajaran berbasis budaya membuat siswa lebih mandiri dan memberikan peluang siswa untuk lebih mengeksplor kemampuannya sendiri baik itu pengetahuan awal maupun keyakinannya. Selain itu, pembelajaran berbasis budaya merupakan pembelajaran yang mengutamakan keaktifan siswa, baik ketika jam pelajaran, maupun di luar jam pelajaran. Hal ini dikarenakan siswa dituntut untuk mencari informasi mengenai sesuatu hal di luar jam pelajaran yang kemudian akan dibahas ketika jam pelajaran dimulai. Oleh karena itu, siswa dapat terjun langsung kedunia nyata dan menerapkan konsep-konsep yang ada, sehingga pembelajaran berbasis budaya mampu menggeser pembelajaran dari pembelajaran yang menggunakan hafalan menjadi pembelajaran yang menghubungkan suatu konsep dengan fakta yang ada dalam kehidupan sehari-hari.

Ketiga, pembelajaran berbasis budaya didisain berdasarkan prinsip-prinsip pembelajaran konstruktivisme di mana pengetahuan dibangun sendiri oleh siswa (student centered), sedangkan guru hanya sebagai fasilitator dan mediator. Guru tidak perlu mentransfer semua pengetahuan kepada pebelajar tetapi mengajak pebelajar untuk berpikir dan mencari jawaban sendiri atas permasalahan yang diberikan oleh guru maupun pebelajar itu sendiri melalui diskusi kelas maupun diskusi kelompok berdasarkan pengalaman mereka yang telah diperoleh dari kehidupan sehari-hari. Beberapa kendala yang dialami guru dalam melaksanakan pembelajaran berbasis budaya adalah dalam memperkenalkan istilah-istilah budaya lokal seperti saling diman, saling kedeng, saling gelut, dan lain-lain khususnya bagi siswa yang bukan orang asli Bali atau anak "kota" mengalami kesulitan. Meskipun demikian, guru menjelaskan secara ringkas istilah-istilah yang baru bagi siswa.

Berdasarkan pemaparan tersebut, maka terbukti secara empiris dan teoretis bahwa pembelajaran berbasis budaya dapat meningkatkan prestasi belajar siswa. Atau 
dengan kata lain, pembelajaran berbasis budaya sangat efektif diterapkan dalam pembelajaran bahasa Indonesia sebagai upaya untuk mengembangkan kompetensi dasar yang ingin dicapai. Atas dasar penilain dari uji coba ini, maka dapat dikatakan bahwa bahan ajar yang dikembangkan layak dipakai sebagai media dalam proses pembelajaran.

\section{Hasil Respon Siswa Terkait Implemetasi Bahan Ajar Bahasa Indonesia Berbasis Budaya Bali}

Untuk menjaring respon siswa terkait efektivitas pengembangan bahan ajar bahasa Indonesia berbasis budaya lokal Bali, digunakan anngket tertutup yang terdiri atas delapan pertanyaan, diantaranya (1) Apakah bahan ajar yang dikembangkan sesuai dengan karakteristik kehidupan nyata Anda?, (2) Apakah penggunaan bahasa dalam uraian materi pada bahan ajar mudah dipahami?, (3) Apakan menurutmu gambar berguna untuk membantu memudahkan menguasai materi?, (4) Apakah contoh yang diberikan membantu Anda memahami materi?, (5) Apakah bahan ajaryang dikembangkan membuat Anda bersemangat untuk belajar?, (6) Apakah bahan ajaryang dikembangkan merangsang rasa ingin tahu Anda?, (7) Apakah bahan ajar yang dikembangkan dapat meningkatkan perhatian Anda untuk belajar?, (8) Apakah bahan ajar yang dikembangkan dapat membuat Anda belajar mandiri?. Berikut ini disajikan data hasil angket berupa respon siswa terhadap penggunaan bahan ajar Bhasa Indonesia berbasis budaya lokal Bali dalam pembelajaran.

Tabel 7. Hasil angket respon mahasiswa terhadap penggunaan bahan ajar Bahasa Indonesia berbasis budaya lokal Bali dalam pembelajaran

\begin{tabular}{|c|c|c|c|c|c|c|c|}
\hline \multirow[t]{2}{*}{ No Pertanyaan } & \multicolumn{5}{|c|}{ Pilihan Jawaban } & \multirow[t]{2}{*}{ Rerata } & \multirow[t]{2}{*}{ Kategori } \\
\hline & 5 & 4 & 3 & 2 & 1 & & \\
\hline 1 & 16 & 5 & - & - & - & 4,76 & Sangat Positif \\
\hline 2 & 12 & 9 & - & - & - & 4,57 & Sangat Positif \\
\hline 3 & 17 & 4 & - & - & - & 4,80 & Sangat Positif \\
\hline 4 & 9 & 12 & - & - & - & 4,42 & Positif \\
\hline 5 & 8 & 13 & - & - & - & 4,38 & Positif \\
\hline 6 & 10 & 11 & - & - & - & 4,47 & Positif \\
\hline 7 & 15 & 6 & - & - & - & 4,71 & Sangat Positif \\
\hline 8 & 10 & 11 & - & - & - & 4,47 & Positif \\
\hline \multicolumn{6}{|c|}{ Total Skor Rerata } & 4,45 & Positif \\
\hline
\end{tabular}

Berdasarkan tabel hasil angket di atas, terlihat bahwa siswa merespon positif penggunaan bahan ajar bahasa Indonesia berbasis budaya lokal Bali pada materi Teks Deskripsi dengan rata-rata respon adalah 4,45 dalam kategori positif.

Selain terdapat pertanyaan tertutup pada angket yang diberikan juga terdapat satu pertanyaan terbuka, yakni mengenai komentar secara garis besar mengenai bahan ajar yang digunakan. Secara garis besar komentar siswa pada tahap lapangan ini yakni sudah sangat baik. Namun, beberapa siswa masih menemukan adanya kesalahan pengetikan. Akan tetapi, intensitas kesalahannya sangat sedikit. Hal ini menunjukkan bahwa keantusiasan siswa dalam memperhatikan bahan ajar sangat tinggi. Penggunaan bahasa yang jelas pada bahan ajar sangat menentukan pemahaman siswa terhadap materi yang disajikan. Oleh sebab itu, bahan ajar haruslah 
memperhatikan aspek kebahasaan terlebih bahan ajar bahasa Indonesia.

\section{PENUTUP}

\section{Simpulan}

Beradasarkan hasil penelitian yang telah dilakukan, maka dapat disimpulkan hal-hal sebagai berikut.

1. Bahan ajar yang dikembangkan dalam penelitian pengembangan ini adalah berupa Handout yang terdiri atas standar kompetensi, kompetensi dasar, ringkasan materi pelajaran, latihan dan sumber bacaan.Hasil analisis penelitian pengembangan ini menunjukkan bahwa pengembangan bahan ajar bahasa Indonesia berbasis budaya lokal bali pada materi Teks Deskripsi sangat baik. Hal itu dapat dibuktikan berdasarkan validasi oleh ahli menyatakan bahan ajar ini berada pada kualifikasi baik dengan skor rata-rata 88,42. Hasil uji coba, baik uji coba lapangan awal dan uji coba lapangan utama menunjukkan skor rata-rata 90,28 dan 92,50. Selain itu, bahan ajar yang dikembangkan juga mampu meningkatkan aktivitas dan hasil belajar siswa dan memfasilitasi siswa untuk memahami budaya lokal melalui materi yang disajikan.

2. Respons siswa terkait pengembangan bahan ajar berbasis budaya lokal Bali menunjukkan hasil yang sangat positif dengan nilai 4,45. Hal ini dibuktikan dengan antusiasme para siswa dalam mengikuti pembelajaran sehingga berdampak pada meningkatnya aktivitas dan hasil belajar siswa.
Berdasarkan temuan-temuan dalam penelitian, beberapa saran yang peneliti dapat ajukan sebagai berikut.

1. Kepada guru mata pelajaran bahasa Indonesia, hasil penelitian ini, dapat dijadikan materi ajar untuk melatih kemampuan siswa dalam memahami teks deskripsi dengan memanfaatkan budaya lokal yang ada di Bali.

2. Bagi peneliti lain, diharapkan dapat melaksanakan penlitian yang sejenis dengan melibatkan subjek yang lebih luas dan mengkaji halhal yang belum diteliti dalam penelitian ini.

\section{DAFTAR PUSTAKA}

Barnhardt, R. (n.d.). Teaching/Learning accros Culture: Strategis for Succes. [Online]. Tersedia: http://www.ankn.uaf.edu/TLAC.hy ml. [5 Mei 2016].

Direktorat Pembinaan Sekolah Menengah Atas. (2008). Panduan Pengembangan Bahan Ajar. Jakarta: Departemen Pendidikan Nasional.

Haukoos, G. \& LeBeau, D. (1992). "Inservice Activity that Emphasizes the Importance of the Cultural in Teaching School Science". Journal of American Indian EducationArizona State University. 32(1). [Online]. Tersedia: http://jaie.asu.edu/v34/ V34S2imp.htm. [5 Mei 2016].

Iskandarwassid dan Dadang Suhendar. 2009. Perspektif Pembelajaran. Bandung: PT Remaja Rosada.

Jegede, O. J. \& Aikenhead, G.S. (n.d.). Transcending Cultural Borders: Implications for Science Teaching. Tersedia: http://www.whk.edu.hk/cridal/ misc/jegede.htm. [09 Mei 2016].

Sardjiyo \& Pannen, P. (2005). "Pembelajaran Berbasis Budaya: Model Inovasi Pembelajaran dan Implementasi Kurikulum Berbasis 
Kompetensi." Jurnal Pendidikan. 6(2), 83-98.

Stephens, S. (2000). Handbook for Culturally Responsive Science Curriculum. Fairbanks: Alaska Native Knowledge Network.

Suastra, I.W, K. Tika, N. Kariasa. (2009). Pengembangan Model Pembelajaran Sains Berbasis Budaya Lokal di SMP. Laporan Penelitian. Tidak Dipublikasikan.

Suastra, I W., K. Tika, N Kariasa. (2011). Efektivitas Model Pembelajaran Sains Berbasis Budaya Lokal Untuk Mengembangkan Kompetensi Dasar Sains Dan Nilai Kearifan Lokal Di SMP. Jurnal Penelitian dan Pengembangan Pendidikan 5(3), 258-273 JPPP. Lembaga Penelitian Undiksha, Desember 2011.

Suja, I W., Sudria IBN., \& Muderawan, I W. (2007). Integrasi Sains Asli (Indigeneous Science) ke dalam Kurikulum Sains Sekolah sebagai Upaya Pengembangan Pendidikan Sains Berbasis Content dan Context Budaya Bali. Laporan Penelitian. Tidak Diterbitkan.

Suryaman Maman. (2012). Bahan Ajar Bahasa Indonesia SMK. Makalah online diterbitkan pada tahun 2012.

Wahyudi (2007). Kurikulum IPA Berbasis Budaya Lokal. [Online]. Tersedia: http://www.duniaguru.com. [5 Mei 2016].

Wijaya, Putu Dewa dan Muhammad Rohmadi. 2009. Analisis WacanaPragmatik: Kajian Teori dan Analisis. Surakarta: Yuma Pressindo.

Tegeh, I Made. dan I Made Kirna. (2010). Pengembangan Bahan Ajar Metode Penelitian Pengembangan Pendidikan Dengan ADDIE Model. Laporan Penelitian Puslit (tidak terpublikasika 
